The University of Maine

\title{
DigitalCommons@UMaine
}

Earth Science Faculty Scholarship

Earth Sciences

6-1-1996

\section{Prismatine: Revalidation for Boron-Rich Compositions in the Kornerupine Group}

Edward S. Grew

University of Maine - Main, esgrew@maine.edu

Mark A. Cooper

Frank C. Hawthorne

Follow this and additional works at: https://digitalcommons.library.umaine.edu/ers_facpub Part of the Earth Sciences Commons

\section{Repository Citation}

Grew, Edward S.; Cooper, Mark A.; and Hawthorne, Frank C., "Prismatine: Revalidation for Boron-Rich Compositions in the Kornerupine Group" (1996). Earth Science Faculty Scholarship. 72.

https://digitalcommons.library.umaine.edu/ers_facpub/72 


\title{
Prismatine: revalidation for boron-rich compositions in the kornerupine group
}

\author{
EDWARD S. GREW \\ Department of Geological Sciences, Universtity of Maine, 5711 Boardman Hall, Orono, ME 04469-5711, USA \\ Mark A. Cooper and Frank C. Hawthorne \\ Department of Geological Sciences, University of Manitoba, Winnipeg, Manitoba, R3T 2N2 Canada
}

\begin{abstract}
Kornerupine and prismatine were introduced independently by Lorenzen in 1884 (but published in 1886 and 1893 ) and by Sauer in 1886, respectively. Ussing (1889) showed that the two minerals were sufficiently close crystallographically and chemically to be regarded as one species. However, recent analyses of boron using the ion microprobe and crystal structure refinement, indicate that the boron content of one tetrahedral site in kornerupine ranges from 0 to 1 . Kornerupine and prismatine, from their respective type localities of Fiskenæsset, Greenland and Waldheim, Germany, are distinct minerals, members of an isomorphic series differing in boron content. For this reason, we re-introduce Sauer's name prismatine for kornerupines with B > 0.5 atoms per formula unit (p.f.u.) of $22(\mathrm{O}, \mathrm{OH}, \mathrm{F})$, and restrict the name kornerupine sensu stricto to kornerupines with $\mathrm{B}<0.5$ p.f.u. Kornerupine sensu lato is an appropriate group name for kornerupine of unknown boron content. Kornerupine sensu stricto and prismatine from the type localities differ also in $\mathrm{Fe}^{2+} / \mathrm{Mg}$ ratio, $\mathrm{Si}-\left(\mathrm{Mg}+\mathrm{Fe}^{2+}+\mathrm{Mn}\right)$ content, $\mathrm{Al}$ content, $\mathrm{F}$ content, colour, density, cell parameters, and paragenesis. Both minerals formed under granulite-facies conditions with sapphirine and phlogopite, but kornerupine sensu stricto is associated with anorthite and hornblende or gedrite, whereas prismatine is found with oligoclase (An9-13), sillimanite, garnet, and/or tourmaline. Occurrences at other localities suggest that increasing boron content extends the stability range of prismatine relative to that of kornerupine sensu stricto.
\end{abstract}

KEYwORDS: prismatine, kornerupine, boron, Waldheim (Germany).

\section{Introduction}

Mineralogists have been slow to recognize the role of boron in kornerupine (Lorenzen, 1886, 1893) and prismatine (Sauer, 1886), largely because of the difficulty in analysing this constituent in refractory silicate minerals, whether by wet chemistry (e.g. Hey et al., 1941) or by microprobe methods. As a result of recent advances in the technology of ion- and

This paper is dedicated to the memory of Gerhard Mathé, who contributed so much to the study reported in this paper.

Diese Publikation ist dem Andenken an Gerhard Mathé gewidmet, der viel zum Gelingen dieser Studie beigetragen hat.

Mineralogical Magazine, June 1996, Vol. 60, pp. 483-491

(C) Copyright the Mineralogical Society electron-microprobe analysis and of crystal-structure refinement, accurate measurement of boron in silicate minerals has become more feasible. New data on the boron contents of kornerupine, including specimens from the type localities of Fiskenæsset, Greenland (kornerupine) and Waldheim, Germany (prismatine), show that kornerupine and prismatine are distinct minerals.

In the present paper, we revalidate the name prismatine for boron-rich kornerupine $(\mathrm{B}>0.5$ atoms per formula unit of $22(\mathrm{O}, \mathrm{OH}, \mathrm{F})$, i.e. $>50 \% \mathrm{~B}$ at the $T 3$ site, which is the only tetrahedral site occupied by boron (Moore and Araki, 1979, whose terminology is used for the irregular cubic site $X$, five octahedral sites $M$ and three tetrahedral sites $T)$ :

${ }^{X}(\square, \mathrm{Fe}, \mathrm{Mg})^{M 1,2,4}(\mathrm{Mg}, \mathrm{Al}, \mathrm{Fe})_{5}{ }^{M 3,5} \mathrm{Al}_{4}{ }^{T 1} \mathrm{Si}_{2}$ ${ }^{T 2}(\mathrm{Si}, \mathrm{Al})_{2}{ }^{T 3}(\mathrm{~B}, \mathrm{Si}, \mathrm{Al})(\mathrm{O}, \mathrm{OH}, \mathrm{F})_{22}$, 
the formula for prismatine. Kornerupine sensu stricto applies to kornerupine with $\mathrm{B}<0.5$ p.f.u., whereas kornerupine sensu lato is the group name for a kornerupine-structure mineral of unspecified boron content. This revision in the nomenclature has been approved by the Commission on New Minerals and Mineral Names of the International Mineralogical Association. In addition, we concur with Friend (1995) that the term boron-free kornerupine sensu stricto be restricted to kornerupine analysed for boron and found not to contain it.

\section{Brief history of the name prismatine}

Sauer (1886) proposed the name prismatine for a prismatic mineral from a cut near the Waldheim railroad station, Saxony, Germany. This mineral resembled sillimanite and andalusite in appearance and staurolite in composition. At that time Sauer was presumably unaware of Lorenzen's (1886) name kornerupine for a mineral from Fiskenasset, Greenland, of composition $\mathrm{MgAl}_{2} \mathrm{SiO}_{6}$ and resembling kyanite and sillimanite.

Ussing (1889) compared Sauer's prismatine with Lorenzen's kornerupine and concluded that they were the same mineral on the basis of symmetry, cleavage and optical orientation; differences in optic angle, colour and specific gravity were presumed to be within the ranges found in isomorphic minerals. The name kornerupine has been given priority because Lorenzen's report was due to be published in 1884 , but was delayed until 1893 (see Lorenzen, 1886; Grew et al., 1987). Compared with kornerupine, prismatine was found to contain less $\mathrm{Al}$, more
Fe and substantially more alkalis (Table 1). Uhlig (1910) cited the alkali content as being sufficient to define prismatine as a distinct species linked in an isomorphic series to kornerupine through the substitution $\mathrm{NaH} \rightleftharpoons \mathrm{Mg}$ :

Prismatine: $(\mathrm{NaH}) \mathrm{H}_{2} \mathrm{Mg}_{6} \mathrm{Al}_{12} \mathrm{Si}_{7} \mathrm{O}_{40}$ Kornerupine: $(\mathrm{Mg}) \mathrm{H}_{2} \mathrm{Mg}_{6} \mathrm{Al}_{12} \mathrm{Si}_{7} \mathrm{O}_{40}$

Goßner and Mußgnug (1928) referred to the mineral as prismatine and cited $\mathrm{X}$-ray data as evidence that kornerupine and prismatine were virtually identical. A few authors have applied the term prismatine to material from localities other than Waldheim (e.g. Kuryleva, 1960). However, since 1928 , most authors have only used the term specifically for the Waldheim mineral (e.g. Hey et al., 1941, p. 122, wrote "...a prismatine from Waldheim, Saxony,..."). Scheumann (1960) concluded that prismatine was an intermediate member in the isomorphic kornerupine series, and suggested that the term prismatine should be used only in reference to material with the distinctive prismatic habit. Nonetheless, even relatively recently, Seifert $(1975$, p. 81$)$ referred to the "sodium-rich variety prismatine" linked to kornerupine through the substitution $\mathrm{Na}+(\mathrm{Mg}, \mathrm{Fe})=\mathrm{Al}$. Thus, the name prismatine has persisted in the literature for nearly 100 years after its introduction.

\section{Relation of studied samples to type material}

We have analysed four prismatine specimens using crystal-structure refinement (Hawthorne et al., 1995) and electron-microprobe analysis. Specimen no. $5105 \mathrm{x}$ (our number) was provided by $\mathrm{K}$. Hoth,

TABLE 1. Wet-chemical analyses of prismatine from Waldheim, Germany (in wt.\%)

\begin{tabular}{|c|c|c|c|c|}
\hline & $\begin{array}{l}\text { Sauer } \\
(1886)\end{array}$ & $\begin{array}{l}\text { Uhlig } \\
\text { (1910) }\end{array}$ & $\begin{array}{c}\text { Goßner and } \\
\text { Mußgnug } \\
(1928)\end{array}$ & $\begin{array}{c}\text { Hey } \\
\text { et al. } \\
(1941)\end{array}$ \\
\hline $\mathrm{SiO}_{2}$ & 30.89 & 30.61 & 33.20 & 30.5 \\
\hline $\mathrm{TiO}_{2}$ & - & 0.30 & - & - \\
\hline $\mathrm{B}_{2} \mathrm{O}_{3}$ & - & - & - & 3.0 \\
\hline $\mathrm{Al}_{2} \mathrm{O}_{3}$ & 43.06 & 42.11 & 42.36 & 35.8 \\
\hline $\mathrm{Fe}_{2} \mathrm{O}_{3}$ & - & 2.21 & 0.30 & 3.2 \\
\hline $\mathrm{FeO}$ & 6.28 & 4.51 & 5.81 & 9.1 \\
\hline $\mathrm{MgO}$ & 15.08 & 15.23 & 11.76 & 17.6 \\
\hline $\mathrm{Na}_{2} \mathrm{O}$ & 2.04 & 1.85 & 5.07 & 1.6 \\
\hline $\mathrm{K}_{2} \mathrm{O}$ & 0.79 & 0.85 & 0.83 & trace \\
\hline $\mathrm{H}_{2} \mathrm{O}$ & 1.36 & 1.94 & 1.60 & - \\
\hline Moisture & - & 0.14 & - & - \\
\hline Total & 99.50 & 99.75 & $100.97^{*}$ & 100.8 \\
\hline
\end{tabular}

*Total as given. The reported values sum to $100.93 \%$. 
Vice-President of the Sächsisches Landesamt für Umwelt und Geologie, Bereich Boden und Geologie, which is the successor to the Geologische Landesuntersuchung Sachsen, where Sauer was working when he discovered prismatine. Hoth (pers. comm. to E. Grew, 1994) wrote that this specimen is "a piece of Prismatingranulit, which belongs to the material studied by A. Sauer and had been collected by him from the classic locality at the exposure near the Waldheim Bahnhof (Sauer, 1886)". The specimen was collected in 1885 , when the outcrop of granulite was first exposed by construction at the Waldheim railroad station (Purgold, 1886, 1887).

Specimen no. 1892.1438 from the Geologisk Museum (Copenhagen) was used by Ussing (1889) to demonstrate that prismatine and kornerupine were identical. The museum label reads 'A. Sauer leg.', that is, collected by Sauer; Ussing (1889) reported that the specimen had been given to him by $\mathbf{H}$. Rosenbusch.

Specimen no. 5105M (Grew's number) is from the collection of the 'Mineralogische Schausammlung', Technische Universität Berlin. The museum label reads 'Credner leg. 1898', that is, it was collected by H. Credner, who was director of the Royal Geological Survey of Saxony.

Specimen 12567 is from the American Museum of Natural History, which acquired it in 1908.

Strictly speaking, none of the analysed samples is holotype material. Specimens 5105x and 1892.1438 could be co-type. In any case, there is a close correspondence between our samples and Sauer's (1886) description. We have no doubt that all four samples come from the same lens of granulite exposed in a roadcut near the railroad station, and reported to be only some $3 \mathrm{~m}$ thick and to extend 15 $m$ (Kalkowsky, 1907). No other exposure of kornerupine- or prismatine-bearing rock was discovered in Waldeim until the 1980s (Grew, 1989). Differences in the compositions reported by Sauer and by us can be attributed to variations in $\mathrm{Fe}^{2+} / \mathrm{Mg}$ ratio from sample to sample, to possible plagioclase impurities in Sauer's material, and to Sauer having overlooked the presence of boron.

\section{Rationale for reviving the name prismatine}

More recent analyses of kornerupine sensu stricto and prismatine have confirmed the differences in $\mathrm{Al}$ and $\mathrm{Fe}$ discussed by Ussing (1889). However, no electron-microprobe analysis of prismatine from Waldheim has shown more than 0.2 wt. $\% \mathrm{Na}_{2} \mathrm{O}$ (Schreyer et al., 1975; Grew, 1986; Grew et al., 1990; this report, Table 2); thus prismatine is not a sodian variety of kornerupine (Schreyer et al., 1975). Lacroix and de Gramont (1919) first reported that prismatine contained substantial boron, which was shown to be in tetrahedral coordination from infrared data (Moenke, 1962; Povarennykh, 1970). However, the data available to Scheumann (1960) were insufficient for him to distinguish prismatine and kornerupine sensu stricto on the basis of boron content.

Distinguishing kornerupine sensu stricto and prismatine on the basis of boron content was really not possible until crystal-structure refinements showed that the B content at 73 was highly variable (e.g. Moore and Araki, 1979; Klaska and Grew, 1991). Recent analyses, including 40 compositions determined by electron-microprobe analysis, ionmicroprobe analysis (SIMS), site-scattering refinement and stereochemical analysis (Hawthorne et al., 1995; Cooper and Hawthorne, unpub. data), show that there is continuous variation in composition and structure between prismatine and kornerupine sensu stricto (Fig. 1).

Crystal-structure refinements of three prismatines from Waldeim confirm ion-microprobe data indicating that these contain more $\mathrm{B}$ than $\mathrm{Si}$ or $\mathrm{Al}$ at the T3 site (i.e. $0.73-0.84 \mathrm{~B}$, Table 2 ); an exception is $0.45 \mathrm{~B}$ measured on fine-grained material in one sample (Grew et al., 1990; Fig. 2, this paper). Electron-microprobe analyses of three prismatine grains in a sample from Sauer's collection (\#5105x, Table 2) are consistent with comparably high boron content. On the other hand, wet-chemical analysis, ion-microprobe analyses, and a combination of sitescattering and mean bond-lengths on Fiskenæsset kornerupine sensu stricto, including the type

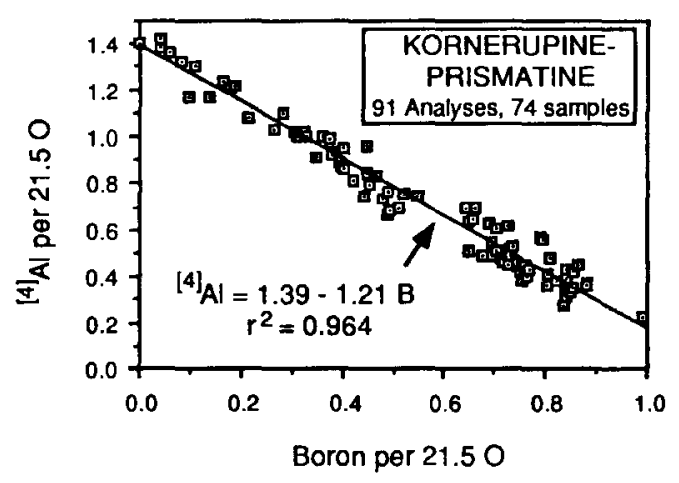

FIG. 1. Plot of 91 kornerupine (here sensu stricto) and prismatine compositions obtained on 74 samples in terms of boron and ${ }^{14 \mathrm{l}} \mathrm{Al}$ (calculated from $5-\mathrm{Si}-\mathrm{B}-\mathrm{Be}$ ) per formula unit of 21.5 oxygens. Sources of data are Table 2; Grew et al. (1987, 1990); Friend, 1995; Cooper and Hawthorne, unpublished data; and the literature cited in Grew (in prep.). 
TABLE 2. Compositions and cell parameters of kornerupine sensu stricto and prismatine from Fiskenæsset, Greenland and Waldheim, Germany

\begin{tabular}{|c|c|c|c|c|c|c|c|}
\hline & $\begin{array}{c}\text { Kornerupine } \\
31498 \\
\text { Fiskenæsset }\end{array}$ & $\begin{array}{c}\text { Prismatine } \\
\text { 5105C } \\
\text { Bahnhof }\end{array}$ & $\begin{array}{c}\text { Prismatine } \\
12567 \\
\text { Bahnhof }\end{array}$ & $\begin{array}{c}\text { Prismatine } \\
5105 \mathrm{M} \\
\text { Bahnhof }\end{array}$ & $\begin{array}{c}\text { Prismatine } \\
1892.1438 \\
\text { Bahnhof }\end{array}$ & $\begin{array}{c}\text { Prismatine } \\
5105 x \\
\text { Bahnhof }\end{array}$ & $\begin{array}{c}\text { Prismatine } \\
\text { 5126AA } \\
\text { Eichberg }\end{array}$ \\
\hline \multicolumn{8}{|c|}{ Electron Microprobe Analyses - wt.\%. } \\
\hline $\mathrm{SiO}_{2}$ & 29.78 & 29.97 & 30.26 & 30.85 & 31.06 & 30.38 & 30.74 \\
\hline $\mathrm{TiO}_{2}$ & 0.08 & 0.27 & 0.23 & 0.21 & 0.21 & 0.23 & 0.21 \\
\hline $\mathrm{Al}_{2} \mathrm{O}_{3}$ & 45.72 & 42.01 & 41.67 & 41.61 & 41.62 & 42.23 & 41.42 \\
\hline $\mathrm{Cr}_{2} \mathrm{O}_{3}$ & 0.02 & 0.07 & 0.12 & 0.12 & 0.19 & 0.11 & 0.12 \\
\hline $\mathrm{V}_{2} \mathrm{O}_{3}$ & b.d. & - & 0.10 & 0.12 & 0.14 & 0.11 & 0.11 \\
\hline $\mathrm{FeO}$ & 1.38 & 6.40 & 8.44 & 5.74 & 4.91 & 6.65 & 5.77 \\
\hline $\mathrm{MnO}$ & b.d. & 0.09 & 0.09 & 0.05 & b.d. & 0.08 & 0.06 \\
\hline $\mathrm{MgO}$ & 19.45 & 15.36 & 13.03 & 15.18 & 16.21 & 14.41 & 15.39 \\
\hline $\mathrm{CaO}$ & 0.08 & 0.03 & b.d. & b.d. & b.d. & b.d. & b.d \\
\hline $\mathrm{Na}_{2} \mathrm{O}$ & b.d. & 0.14 & 0.07 & 0.10 & 0.14 & 0.08 & 0.09 \\
\hline $\mathrm{K}_{2} \mathrm{O}$ & b.d. & b.d. & b.d. & b.d. & - & - & b.d. \\
\hline $\mathrm{F}$ & b.d. & - & 0.76 & 0.76 & 0.89 & 0.60 & 0.78 \\
\hline \multicolumn{8}{|c|}{ Crystal Structure Refinement - wt.\%. } \\
\hline $\mathrm{B}_{2} \mathrm{O}_{3}$ & 1.47 & - & 3.94 & 3.75 & 3.59 & - & 3.92 \\
\hline \multicolumn{8}{|c|}{ Ion Microprobe Analysis - wt.\%. } \\
\hline $\mathrm{B}_{2} \mathrm{O}_{3}$ & $1.35^{* *}$ & 3.40 & $3.98 * *$ & $3.70^{* *}$ & - & - & $4.05^{* *}$ \\
\hline $\mathrm{F}$ & - & 0.73 & - & - & - & - & - \\
\hline \multicolumn{8}{|c|}{ Calculated - wt. $\%$. } \\
\hline $\mathrm{H}_{2} \mathrm{O}$ & 1.22 & 0.86 & 0.84 & 0.85 & 0.79 & - & 0.84 \\
\hline$-\mathrm{O}=\mathrm{F}$ & 0 & -0.31 & -0.32 & -0.32 & -0.37 & -0.25 & -0.33 \\
\hline Total & $99.18^{\$}$ & 99.15 & $99.23^{\$}$ & $99.02^{\$}$ & $99.37^{\$}$ & 94.64 & $99.12^{\mathrm{s}}$ \\
\hline \multicolumn{8}{|c|}{ Formulae per $21 \mathrm{O}+1(\mathrm{OH}, \mathrm{F})$} \\
\hline $\mathrm{Si}$ & 3.668 & 3.741 & 3.791 & 3.831 & 3.836 & - & 3.813 \\
\hline $\mathrm{B}$ & $0.313^{*}$ & 0.733 & $0.852 *$ & $0.804 *$ & $0.764 *$ & - & $0.839 *$ \\
\hline $\mathrm{Al}$ & 6.637 & 6.180 & 6.152 & 6.090 & 6.058 & - & 6.055 \\
\hline $\mathrm{Ti}$ & 0.007 & 0.025 & 0.022 & 0.020 & 0.020 & - & 0.020 \\
\hline $\mathrm{Cr}$ & 0.000 & 0.007 & 0.012 & 0.012 & 0.019 & - & 0.012 \\
\hline $\mathrm{V}$ & 0.000 & - & 0.010 & 0.012 & 0.014 & - & 0.011 \\
\hline $\mathrm{Fe}^{2+}$ & 0.142 & $0.668 \#$ & $0.884 \#$ & $0.596 \#$ & $0.507 \#$ & - & 0.598 \\
\hline $\mathrm{Mn}$ & 0.000 & 0.010 & 0.010 & 0.005 & 0.000 & - & 0.006 \\
\hline $\mathrm{Mg}$ & 3.572 & 2.858 & 2.433 & 2.810 & 2.984 & - & 2.846 \\
\hline $\mathrm{Ca}$ & 0.011 & 0.004 & 0.000 & 0.000 & 0.003 & - & - \\
\hline $\mathrm{Na}$ & 0.000 & 0.034 & 0.017 & 0.024 & 0.034 & - & 0.022 \\
\hline Total & 14.350 & 14.321 & 14.183 & 14.203 & 14.234 & - & 14.220 \\
\hline \multicolumn{8}{|c|}{ T3 occupancies (combined site-scattering and mean bond-lengths) } \\
\hline Si & 0.44 & - & 0.08 & 0.12 & 0.12 & - & 0.10 \\
\hline $\mathrm{Al}$ & 0.24 & - & 0.08 & 0.08 & 0.12 & - & 0.06 \\
\hline B & 0.32 & - & 0.84 & 0.80 & 0.76 & - & 0.84 \\
\hline \multicolumn{8}{|c|}{ Anions } \\
\hline $\mathrm{F}$ & 0.000 & 0.288 & 0.301 & 0.298 & 0.348 & - & 0.306 \\
\hline $\mathrm{OH}$ & 1.000 & 0.712 & 0.699 & 0.702 & 0.652 & - & 0.694 \\
\hline
\end{tabular}


Table 2 (cont.)

\begin{tabular}{lccccccc}
\hline & $\begin{array}{c}\text { Kornerupine } \\
31498 \\
\text { Fiskenæsset }\end{array}$ & $\begin{array}{c}\text { Prismatine } \\
5105 \mathrm{C} \\
\text { Bahnhof }\end{array}$ & $\begin{array}{c}\text { Prismatine } \\
12567 \\
\text { Bahnhof }\end{array}$ & $\begin{array}{c}\text { Prismatine } \\
5105 \mathrm{M} \\
\text { Bahnhof }\end{array}$ & $\begin{array}{c}\text { Prismatine } \\
1892.1438 \\
\text { Bahnhof }\end{array}$ & $\begin{array}{c}\text { Prismatine } \\
5105 x \\
\text { Bahnhof }\end{array}$ & $\begin{array}{c}\text { Prismatine } \\
5126 \mathrm{AA} \\
\text { Eichberg }\end{array}$ \\
\hline \multicolumn{7}{c}{ Cell Parameters (Space group Cmcm) } \\
$a(\AA)$ & $16.050(6)$ & - & $15.938(3)$ & $15.949(2)$ & $15.980(3)$ & - & $15.938(2)$ \\
$b(\AA)$ & $13.742(4)$ & - & $13.673(3)$ & $13.669(2)$ & $13.697(2)$ & - & $13.670(3)$ \\
$c(\AA)$ & $6.728(2)$ & - & $6.693(1)$ & $6.692(1)$ & $6.696(2)$ & - & $6.690(1)$ \\
$V\left(\AA^{3}\right)$ & $1483.7(2)$ & - & $1458.5(5)$ & $1459.0(4)$ & $1465.5(5)$ & - & $1457.6(4)$ \\
\hline
\end{tabular}

Notes: Sources of data by column. 1 and 3 to 7 - Mark Cooper and F. C. Hawthorne, unpub. data; 2 - Grew (1986), $\mathrm{Ba}$ and $\mathrm{Sr}$ below detection. Totals include $\mathrm{BeO} 0.007$ and $\mathrm{Li}_{2} \mathrm{O} 0.12 \mathrm{wt} . \%$, and $\mathrm{Be} 0.002$, $\mathrm{Li} 0.060$. Column 6 is average of 3 grains for which FeO varies 6.54-6.82 wt. $\%$, $\mathrm{MgO} 14.26-14.54$ wt. \%, and $\mathrm{Al}_{2} \mathrm{O}_{3} 41.78-42.87$ wt. \% Bahnhof refers to the type locality at the railroad station in Waldheim. Eichberg is situated in Waldheim, $800 \mathrm{~m}$ from the type locality (Grew, 1989). *B values from crystal structure refinement. \#Mössbauer spectroscopy of another sample from Waldheim Bahnhof shows that $<1 \%$ of the $\mathrm{Fe}$ is $\mathrm{Fe}^{3+}$ (Grew, Redhammer and Amthauer, unpub. data). ${ }^{\$}$ Does not include ion microprobe $\mathrm{B}_{2} \mathrm{O}_{3}$ contents. b.d. below detection. ${ }^{* * V a l u e s ~ f r o m ~ H a w t h o r n e ~ e t ~ a l . ~(1995) . ~}$

specimen (no. 1883.754), consistently give less than 0.5 B p.f.u. (Grew et al., 1987, Table 1; this paper, Table 2). The difference in $T 3$ composition between the type kornerupine sensu stricto $(\mathrm{Al}<\mathrm{B}<\mathrm{Si})$ and prismatine $(\mathrm{B} \gg \mathrm{Si}$ and $\mathrm{Al}$ ) is sufficient to recognize prismatine and kornerupine sensu stricto as distinct isostructural species. That is, T3 compositions (see structural formula above) are (B,Si, Al) in prismatine, ( $\mathrm{Si}, \mathrm{B}, \mathrm{Al})$ in borian kornerupine sensu stricto, and ( $\mathrm{Si}, \mathrm{Al})$ in boron-free kornerupine sensu stricto (Klaska and Grew, 1991; Friend, 1995).

For this reason, we re-introduce Sauer's (1886) name prismatine for a kornerupine-structure mineral with B $>0.5$ atoms per formula unit (p.f.u.) of $22(\mathrm{O}, \mathrm{OH}, \mathrm{F})$, and restrict the name kornerupine sensu stricto to kornerupine with $\mathrm{B}<0.5$ p.f.u. Kornerupine sensu lato is an appropriate group name for kornerupine-structure minerals of an unknown boron content. We recommend referring to kornerupine sensu lato simply as kornerupine, and will do so in the remainder of the present paper. Thus, use of the names kornerupine and prismatine would be analogous to the accepted use of the names spinel and hercynite for the group or $\mathrm{Mg}$-dominant member and $\mathrm{Fe}$-dominant member, respectively, of the $\mathrm{MgAl}_{2} \mathrm{O}_{4}$ - $\mathrm{FeAl}_{2} \mathrm{O}_{4}$ series, except that we make a clearer distinction between kornerupine sensu stricto and sensu lato. The modifier 'boron-free' should be applied only to kornerupine sensu stricto with $\mathrm{B}=0$ (Friend, 1995), and the modifier 'boron-poor' is a reasonable term for kornerupine sensu stricto with B $<0.2$, a usage also recommended by Friend (1995). Strictly speaking, the distinction should be $\mathrm{B}>(\mathrm{Si}+$
$\mathrm{Al})$ (prismatine) and $\mathrm{Si}>(\mathrm{B}+\mathrm{Al})$ (kornerupine sensu stricto). However, the amount of $\mathrm{Al}$ at $T 3$ can only be ascertained by crystal-structure refinement, so that including $\mathrm{Al}$ in the definition is not practical.

\section{Comparison of prismatine and kornerupine sensu stricto}

Type kornerupine sensu stricto and prismatine differ not only in B content of the $T 3$ site, but also in $\mathrm{Fe} / \mathrm{Mg}$ ratio, $\mathrm{Si}-\left(\mathrm{Mg}+\mathrm{Fe}^{2+}+\mathrm{Mn}\right)$ content, $\mathrm{Al}$ content, $\mathrm{F}$ content, colour, density and cell parameters (Fig. 2; Tables 2, 3; no optical data were reported for kornerupine sensu stricto except for $-2 \mathrm{E}=$ $14-32.5^{\circ}$ by Ussing, 1889). Of the above listed chemical and physical properties, the cell volume, $a$ and $c$ parameters are most clearly related to the $\mathrm{B}$ content; the $b$ parameter is sensitive to other compositional variables. In principle, the $a$ and $c$ parameters could be used as criteria to distinguish prismatine from kornerupine sensu stricto because all three decrease with B content (e.g. Werding and Schreyer, 1978; Grew et al., 1990). Al content varies inversely with $B$ by virtue of the coupled substitution ${ }^{[T 3]} \mathrm{B}+{ }^{[T 2]} \mathrm{Si} \rightleftharpoons{ }^{\left[{ }^{73}\right]} \mathrm{Si}+{ }^{[T 2]} \mathrm{Al}$, which sums roughly to $\mathrm{B}$ for $\mathrm{Al}$ substitution (Fig. 1); thus $\mathrm{Al}$ content could be used to estimate $\mathrm{B}$ content. However, $\mathrm{Al}$ also varies inversely with $\mathrm{Mg}+\mathrm{Si}$ (Tschermak substitution) and with $\mathrm{Fe}^{3+}$ (e.g. Klaska and Grew, 1991), and thus Al content must be used with caution. Colour and refractive indices vary with $\mathrm{Fe} / \mathrm{Mg}$ ratio, but little, if at all, with B content (e.g. Waters and Moore, 1985). 


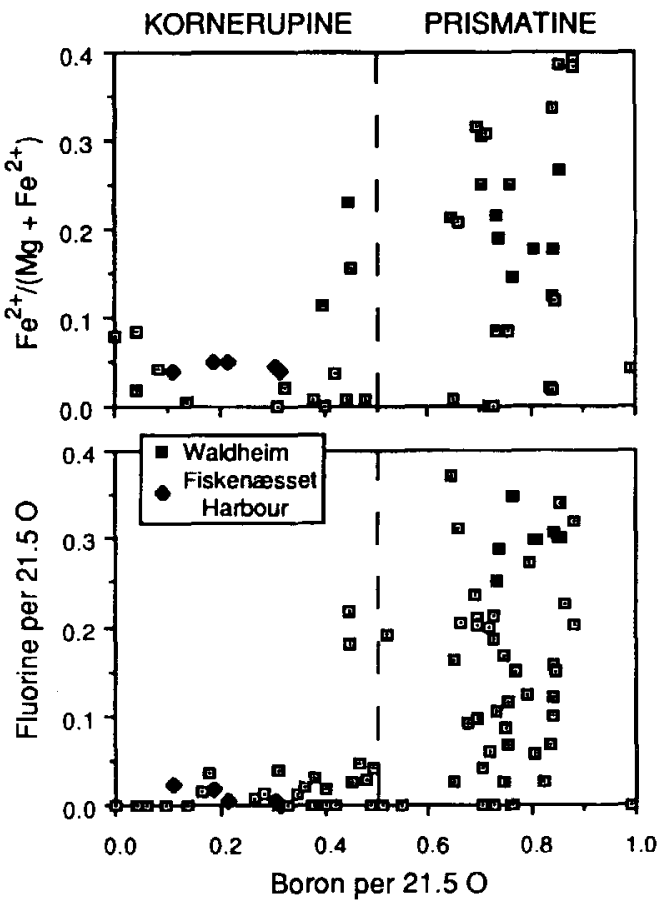

FIG. 2. Plot of kornerupine (here sensu stricto) and prismatine compositions in terms of $\mathrm{B}, \mathrm{Fe}^{2+} /\left(\mathrm{Fe}^{2+}+\mathrm{Mg}\right)$ ratio ( 47 compositions) and $F$ ( 87 compositions). The 49 compositions are those in which $\mathrm{Fe}^{3+} / \mathrm{Fe}^{2+}$ ratio have been estimated from crystallographic, wet-chemical, or Mössbauer data, or in which $\mathrm{Fe}$ as $\mathrm{FeO}<2$ wt.\%. Cooper and Hawthorne's electron microprobe $\mathrm{F}$ values of $0.2 \mathrm{wt} . \%$ or less are plotted as $\mathrm{F}=0$. Sources of data are the same as for Fig. 1.

The minor-element signature of the Waldheim prismatine is distinctive in that $\mathrm{Na}, \mathrm{Ti}, \mathrm{Cr}$, and $\mathrm{V}$ are present in amounts exceeding $0.1 \mathrm{wt} . \%$ oxide. None of these constituents, except Ti, reach $0.1 \mathrm{wt} . \%$ oxide in kornerupine sensu stricto from the type locality, although chromian kornerupine sensu stricto is found elsewhere in the Fiskenæsset complex (Cooper and Hawthorne, unpub. data). The $\mathrm{V}$ content of prismatine is exceeded only by green and blue vanadian prismatine and kornerupine from Kenya and Tanzania (to 0.78 wt. $\% \mathrm{~V}_{2} \mathrm{O}_{3}$, Girgis et al., 1976; Schmetzer et al., 1979).

The compositional differences between type prismatine and type kornerupine sensu stricto characterize these minerals from other localities (Fig. 2). On the one hand, in kornerupine sensu stricto with $\mathrm{B} \leqslant 0.4$ atoms p.f.u., $\mathrm{F}$ contents are negligible and $\mathrm{Mg} \gg \mathrm{Fe}^{2+}$. Variations among the major constituents can be largely expressed by a

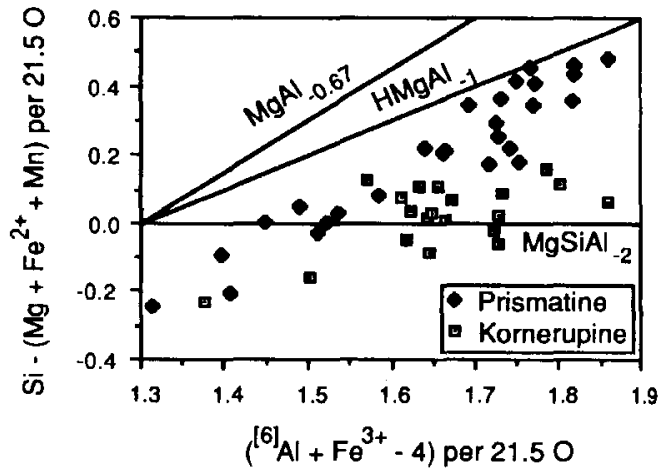

FIG. 3. Plot of the 47 kornerupine (here sensu stricto) and prismatine compositions of known $\mathrm{Fe}^{3+} / \mathrm{Fe}^{2+}$ ratio in terms of $\mathrm{Si}-\left(\mathrm{Mg}-\mathrm{Fe}^{2+}+\mathrm{Mn}\right)$ and ${ }^{[6]} \mathrm{Al}+\mathrm{Fe}^{3+}+(\mathrm{Cr}+$ V) - 4 per formula unit of 21.5 oxygens. Possible substitutions (site terminology of Moore and Araki, 1979) are ${ }^{[X]} \mathrm{Mg}+2^{[M 4]} \mathrm{Mg}=2^{[M 4]}\left(\mathrm{Al}, \mathrm{Fe}^{3+}\right)$ $\left(\mathrm{MgAl}_{-0.67}\right), \mathrm{H}+{ }^{\left[M^{4}\right]} \mathrm{Mg}={ }^{[M 4}\left(\mathrm{Al}, \mathrm{Fe}^{3+}\right)\left(\mathrm{HMgAl}_{-1}\right)$, and $\mathrm{Si}+{ }^{[M 4]} \mathrm{Mg}={ }^{\left[{ }^{[]}\right]}(\mathrm{Al}, \mathrm{B})+{ }^{[M 4]}\left(\mathrm{Al}, \mathrm{Fe}^{3+}\right)\left(\mathrm{MgSiAl}_{-2}\right)$. Sources of data are the same as for Fig. 1.

Tschermak-type substitution involving boron (horizontal line marked $\mathrm{MgSiAl}_{2}$ in Fig. 3), that is, $\mathrm{Si} \approx \mathrm{Mg}+\mathrm{Fe}^{2+}+\mathrm{Mn}$. On the other hand, prismatine (and kornerupine sensu stricto with B $>0.4$ p.f.u.) can contain substantial $\mathrm{F}$ and $\mathrm{Fe}^{2+}$. Prismatine compositions define a trend in Fig. 3 clearly at variance with a Tschermak-type substitution. Another substitution, possibly acting in tandem with a Tschermak-type substitution, is needed to explain compositional variations in prismatine. Two poss le alternatives are indicated in Fig. 3; these inve ve the region around the partially occupied $X$ site Charge balance for the substitution ${ }^{[M 4]} \mathrm{Mg}=$ $\left.{ }^{[M 4}, \mathrm{Al}, \mathrm{Fe}^{3+}\right)$ is attained either by filling the $X$ site its ff with a divalent cation $\left(\mathrm{MgAl}_{-0.67}\right.$, Fig. 3) or by ad ing a proton to the nearby $H$ site $\left(\mathrm{HMgAl}_{-1}\right.$, $\mathbf{F} j$,. 3). The distinction between the trends for p smatine and kornerupine sensu stricto in Fig. 3 c sarly illustrates the effect of boron on other cations.

The parageneses at the type localities are different. '.ornerupine sensu stricto occurs with phlogopite, northite, sapphirine, hornblende, gedrite, spinel, corundum, chlorite and pinite; inferred equilibrium mineral assemblages are kornerupine sensu stricto + hornblende, kornerupine sensu stricto + gedrite, and kornerupine sensu stricto + sapphirine (all with anorthite + phlogopite; Grew et al., 1987). Minerals associated with prismatine are sodic oligoclase (An9-13), kyanite, sillimanite, andalusite, tourmaline, dumortierite, biotite, sapphirine, garnet, corundum, quartz, rutile, muscovite and chlorite, 
TABLE 3. Comparison of the optical, physical, and crystallographic properties of kornerupine sensu stricto and prismatine from Fiskenæsset, Greenland and Waldheim, Germany

\begin{tabular}{|c|c|c|}
\hline & $\begin{array}{l}\text { Kornerupine } \\
\text { Fiskenaasset }\end{array}$ & $\begin{array}{c}\text { Prismatine } \\
\text { Waldheim (Bahnhof) }\end{array}$ \\
\hline \multicolumn{3}{|c|}{ Optical properties } \\
\hline$\alpha$ & - & $1.669-1.671^{2,3}$ \\
\hline$\beta$ & - & $1.681-1.683^{2.3}$ \\
\hline$\gamma$ & - & $1.682-1.684^{2,3}$ \\
\hline $2 V_{a}$ & $8-19^{\circ 2^{*}}$ & $28-38^{\circ 2.3}$ \\
\hline Dispersion & None $^{2}$ & $\mathrm{r}<\mathrm{v}$, weak $^{2,3}$ \\
\hline Colour (hand sp.) & White $^{1}$ & Gold-brown ${ }^{2.3}$ \\
\hline Colour (thin sect.) & Colourless $^{2}$ & Colourless $^{3}$ \\
\hline $\begin{array}{l}\text { Colour (sections } \\
\text { of greater than } \\
\text { standard thickness) }\end{array}$ & - & $\begin{array}{l}\text { Pleochroic: colourless to } \\
\text { greenish, reddish, yellow, } \\
\text { and yellow-brown }\end{array}$ \\
\hline \multicolumn{3}{|c|}{ Physical properties } \\
\hline Density $\left(\mathrm{g} / \mathrm{cm}^{3}\right)$ & $3.23^{1}, 3.273^{2}$ & $3.341-3.345^{2,3}$ \\
\hline Hardness & $6.5^{1,2}$ & $6.5-7.0^{2.3}$ \\
\hline Cleavage & $\{110\}^{2}$ & $\{110\}^{2}$ \\
\hline \multicolumn{3}{|c|}{ Crystallographic properties } \\
\hline$a: b: c$ (morph.) & $1: 0.854:-^{2}$ & $1: 0.862: 0.4345^{3}$ \\
\hline$a: b: c(\mathrm{X}-\mathrm{ray})$ & $1: 0.856: 0.419^{4}$ & $1: 0.857: 0.420^{5}$ \\
\hline
\end{tabular}

Sources: 1. Lorenzen (1886), 2. Ussing (1889), 3. Uhlig (1910), 4. This report, sample 31498. 5. This report, average of the three prismatines from Waldheim Bahnhof in Table 2. * $2 \mathrm{~V}$ calculated from the relation $\sin \mathrm{V}=\sin E / \beta$ (Uhlig, 1910) and Ussing's (1889) $2 \mathrm{E}=14-32.5^{\circ}$ and assuming $\beta=1.68$. Refractive indices were not reported for Fiskenæsset kornerupine sensu stricto.

Ind the inferred equilibrium assemblage at the type ocality is prismatine + biotite + sapphirine + zorundum + sillimanite \pm garnet \pm tourmaline 'Schreyer et al., 1975; Grew, 1986). Prismatine + juartz is a rare assemblage at the type locality, but is zommon at a second Waldheim locality, Eichberg, situated $800 \mathrm{~m}$ to the east (Kalkowsky, 1907; Grew, 1986, 1989); one prismatine from Eichberg contains 0.84 B p.f.u. (Table 2). Kornerupine sensu stricto and prismatine are granulite-facies minerals; at the type localities, estimated conditions of formation are $700-830^{\circ} \mathrm{C}, 5-10 \mathrm{kbar}$ (Grew et al., 1987; Riciputi et al., 1990) and $750-850^{\circ} \mathrm{C}, 5-12.5 \mathrm{kbar}$ (Grew, 1986, Rötzler, 1992), respectively. More recent data on the Saxony granulites, including the Waldheim area, suggest that temperatures and pressures during early stages of prismatine formation could have been as high as $1050^{\circ} \mathrm{C}$ and $20-23 \mathrm{kbar}$ (e.g. Rötzler et al., 1995). Prismatine is inferred to have formed during decompression in close association with anatexis.

Kornerupine sensu stricto with B $<0.4$ p.f.u. is found in $\mathrm{Mg}$-Al-rich, silica-undersaturated rocks metamorphosed under upper amphibolite or granulite-facies conditions, of which the sapphirinekornerupine sensu stricto rocks associated with the Fiskenæsset Complex are a prime example (e.g. Friend, 1995). Many prismatine-bearing rocks are similar in being $\mathrm{Mg}$ - $\mathrm{Al}$-rich and silica-undersaturated; indeed, both minerals have been found at one locality, or even in a single specimen in which B contents vary markedly. However, prismatine parageneses are more diverse, and include assemblages with quartz, andalusite, K-feldspar or grandidierite (e.g. Grew et al., 1990), and host rocks for prismatine are closer to average metapelites at some localities. Other than Waldheim, prismatine is reported to be stable at $T-P$ conditions as extreme as $900^{\circ} \mathrm{C}$, 
$6.5 \mathrm{kbar}$ (Paderu, India, Lal et al, 1987) and $\geqslant 540^{\circ} \mathrm{C}$, $\leqslant 3$ kbar (Homagama, Sri Lanka; Grew et al., 1995). The latter conditions are outside those determined experimentally for $\mathrm{B}$-free kornerupine sensu stricto $\left(T \geqslant 735^{\circ} \mathrm{C}, P_{\mathrm{H}_{2} \mathrm{O}} \geqslant 4.5\right.$; Seifert, 1975), implying thereby that increasing boron content extends the stability range of prismatine relative to that of kornerupine sensu stricto.

\section{Acknowledgements}

We thank the following individuals and/or institutions for samples of prismatine and background information on them: J. Peters of the American Museum of Natural History for \#12567; K. Hoth of the Sächsisches Landesamt für Umwelt und Geologie, Freiberg for a specimen from Sauer's collection (our \#5105x); O. V. Petersen of the Geological Museum of the University of Copenhagen for \#1892.1438; C. Tennyson and S. Herting-Agthe of the Technische Universität Berlin for the specimen collected by Credner (our \#5105M). We are also grateful to Gerhard Mathé for background information and assistance in locating type material, to G. Mathé and J. Hofmann who together introduced the first author to Waldheim and assisted his collecting at the type and Eichberg localities; to $\mathrm{K}$. Thalheim for translation of the dedication, and to A. R. Kampf for his review of an earlier draft. This research was supported by US National Science Foundation grant EAR-9118408 to the University of Maine, and by the Natural Sciences and Engineering Research Council of Canada via Operating, Equipment and Infrastructure Grants to $\mathrm{FCH}$.

\section{References}

Friend, C.R.L. (1995) Occurrences of boron-free and boron-poor kornerupine. Mineral. Mag., 59, 163-6.

Girgis, K. Gübelin, E. and Weibel, M. (1976) Vanadiumhaltiger grüner Kornerupin vom KwaleDistrikt, Kenya. Schweiz. Mineral. Petrogr. Mitteilungen, 56, 65-8.

Goßner, B. and Mußgnug, F. (1928) Vergleichende röntgenographische Untersuchung von Magnesiumsilikaten. Neues Jahrb. Mineral., Geol. u. Paläont., Abt. A, 58, 213-52.

Grew, E.S. (1986) Petrogenesis of kornerupine at Waldheim (Sachsen), German Democratic Republic. Zeits. geol. Wissenschaften, 14, 525-58.

Grew, E.S. (1989) A second occurrence of kornerupine in Waldheim, Saxony, German Democratic Republic. Zeits. geol. Wissenschaften, 17, 67-76.

Grew, E.S., Herd, R.K. and Marquez, N. (1987) Boronbearing kornerupine from Fiskenæsset, West Greenland: a re-examination of specimens from the type locality. Mineral. Mag., 51, 695-708.
Grew, E.S., Chernosky, J.V., Werding, G., Abraham, K, Marquez, N. and Hinthorne, J.R. (1990) Chemistry of kornerupine and associated minerals, a wet chemical, ion microprobe, and X-Ray study emphasizing $\mathrm{Li}, \mathrm{Be}, \mathrm{B}$ and $\mathrm{F}$ contents. J. Petrol., 31, $1025-70$.

Grew. E.S., Hiroi, Y., Motoyoshi, Y., Kondo, Y., Jayaliteke, S.J.M. and Marquez, N. (1995) Iron-rich kornerupine in sheared pegmatite from the Wanni Complex, at Homagama, Sri Lanka. Eur. J. Mineral., 7, 623-36

Hawthorne, F.C., Cooper, M., Bottazzi, P. Ottolini, L. Ercit, T.S. and Grew, E.S. (1995) Micro-analysis of minerals for boron by SREF, SIMS and EMPA: A comparative study. Canad. Mineral., 33, 389-97.

Hey, M.H., Anderson, B.W. and Payne, C.J. (1941) Some new data concerning kornerupine and its chemistry. Mineral. Mag., 26, 119-30.

Kalkowsky, E. (1907) Der Korundgranulit von Waldheim in Sachsen. Sitzungsberichte und Abhandlungen der Naturwissenschaftlichen Gesellschaft Isis in Dresden, 2, 47-65.

Klaska, R. and Grew, E.S. (1991) The crystal structure of boron-free kornerupine: Conditions favoring the incorporation of variable amounts of $\mathrm{B}$ through ${ }^{[4]_{B}} \mathrm{~B}$ $\rightleftharpoons{ }^{[4]} \mathrm{Si}$ substitution in kornerupine. Amer. Mineral., 76, 1824-35.

Kuryleva, N.A. (1960) Prismatine from the Bug River area. Zap. Vses. Mineral. Obshch., 2nd Series, 89, no. 6, 711-3 (in Russian).

Lacroix, A. et de Gramont, A. (1919) Sur la présence du bore dans quelques silico-aluminates basiques naturels. Comptes Rendus de la Académie des Sciences, 168, 857-61.

Lal, R.K., Ackermand, D. and Upadhyay, H. (1987) $P$. $T-X$ relationships deduced from corona textures in sapphirine-spinel-quartz assemblages from Paderu, southern India. J. Petrol., 28, 1139-68.

Lorenzen, J. (1886) Untersuchungen grönländischer Mineralien. Zeitschrift für Kristallographie und Mineralogie, 11, 315-8.

Lorenzen, J. (1893) Undersøgelse af Mineralier fra Grønland. Meddelelser om Grønland, 7, 1-32 [originally scheduled for publication in 1884].

Moenke, H. (1962) Nachweis von $\mathrm{BO}_{3^{-}}$and $\mathrm{BO}_{4^{-}}$ Gruppen in den häufigsten natürlich gebildeten Silikaten. Silikattechnik, 13, 287-8.

Moore, P.B. and Araki, T. (1979) Kornerupine: a detailed crystal-chemical study. Neues Jahrb. Mineral. Abh., 134, 317-36.

Povarennykh, A.S. (1970) Spectres infrarouges de certains minéraux de Madagascar. Bull. Soc. fr. Minéral. Crist., 93, 224-34.

Purgold, A. (1886) Neunte Sitzung an 26. November 1885. Sitzungsberichte und Abhandlungen der Naturwissenschaftlichen Gesellschaft Isis in Dresden, Jahrgang 1885, p. 67-9. 
Purgold, A. (1887) Berichtigung und Ergänzung. Sitzungsberichte und Abhandlungen der Naturwissenschaftlichen Gesellschaft Isis in Dresden, Jahrgang 1886, 2 pages.

Riciputi, L.R., Valley, J.W. and McGregor, V.R. (1990) Conditions of Archean granulite metamorphism in the Godthab-Fiskenaesset region, southern West Greenland. J. Metam. Geol., 8, 171-90.

Rötzler, J. (1992) Zur Petrogenese im Sächsischen Granulitgebirge. Die pyroxenfreien Granulite und die Metapelite. Geotekt. Forsch., 77, 1-100.

Rötzler, J., Hagen, B. and Hörnes, S. (1995) Evidence for ultra-high temperature/high pressure metamorphism in the Saxonian Granulite Massif, Germany. Metamorphic Studies Group, Mineralogical Society of Great Britain and Ireland and Geological Society of London, Research in Progress and Annual General Meeting, Programme and Abstracts, p. 9.

Sauer, A. (1886) Über eine eigenthümliche Granulitart als Muttergestein zweier neuer Mineralspecies. Zeits. Deutschen Geologischen Gesellschaft, 38, 704-6.

Scheumann, K.H. (1960) Das Kornerupingestein von Waldheim in seinem genetischen Zusammenhang. Abhandlungen der Sächsischen Akademie der Wissenschaften zu Leipzig, Math.-naturwissen. Klasse, 47(2), 23 pp.

Schmetzer, K., Ottemann, J., Bank, H. and Krupp, J.
(1979) Transparent bluish-green kornerupine from East Africa (Kenya and Tanzania). J. Gemmol., 16(7), 455-7.

Schreyer, W., Abraham, K. and Behr, H. J. (1975) Sapphirine and associated minerals from the kornerupine rock of Waldheim, Saxony. Neues Jahrb. Mineral. Abh., 126, 1-27.

Seifert, F. (1975) Boron-free kornerupine: A highpressure phase. Amer. J. Sci., 275, 57-87.

Uhlig, J. (1910) Über Prismatin und Kryptotil von Waldheim in Sachsen. Zeits. Krist. Mineral, 47, 215-30.

Ussing, N.V. (1889) XXXIV. Untersuchungen der Mineralien von Fiskernäs in Grönland. Zeits. Krist. Mineral., 15, 596-615.

Waters, D.J. and Moore, J.M. (1985) Kornerupine in $\mathrm{Mg}-\mathrm{Al}$-rich gneisses from Namaqualand, South Africa: mineralogy and evidence for late-metamorphic fluid activity. Contrib. Mineral. Petrol., 91, 369-82.

Werding, G. and Schreyer, W. (1978) Synthesis and crystal chemistry of kornerupine in the system $\mathrm{MgO}-$ $\mathrm{Al}_{2} \mathrm{O}_{3}-\mathrm{SiO}_{2}-\mathrm{B}_{2} \mathrm{O}_{3}-\mathrm{H}_{2} \mathrm{O}$. Contrib. Mineral. Petrol, 67, 247-59.

[Manuscript received 20 January 1995:

revised 2 May 1995] 